\title{
ANALISIS KINERJA PEGAWAI BIDANG PENGENDALIAN DAN PENERTIBAN (DALTIB) PADA DINAS LALU LINTAS DAN ANGKUTAN JALAN DALAM MENGATASI KEMACETAN DI KOTA BOGOR
}

\author{
Dea Siti Hilmiah Halawi ${ }^{1}$, Rita Rahmawati², Euis Salbiah ${ }^{3}$ \\ 1 Jurusan Ilmu Administrasi Negara Fakultas Imu Sosial dan Ilmu Politik Universitas Djuanda, Jl.Tol \\ Ciawi No 1, Kotak Pos 35 Bogor 16770 \\ 2 Jurusan Ilmu Administrasi Negara Fakultas Imu Sosial dan Ilmu Politik Universitas Djuanda, Jl.Tol \\ Ciawi No 1, Kotak Pos 35 Bogor 16770 \\ 3 Jurusan Ilmu Administrasi Negara Fakultas Imu Sosial dan Ilmu Politik Universitas Djuanda, Jl.Tol \\ Ciawi No 1, Kotak Pos 35 Bogor 16770
}

(Diterima oleh Dewan Redaksi: 01-02-2016)

(Dipublikasikan oleh Dewan Redaksi: 01-04-2016)

\begin{abstract}
Traffic Jam is a major problem many cities in Indonesia, including in Bogor city. Traffic Jam in Bogor city is almost equal to the capital city of Jakarta. There are many factors that caused traffic jam in Bogor. In addition to the number of population is increasing, mobility of the population is also quite high. The purpose of this study was to determine employees performance of Department of Traffic and road transportation Bogor in handling of traffic jam. The method used in this research is survey method with quantitative approach. The results showed that the views of the dimensions of productivity, quality of service, responsiveness, responsibility, and accountability are very good category. Although the results of employee respondents considered that the assessment of employee performance has been very good, but in the view of the driver, passengers and road users were different. They noticed that traffic jam in Bogor City can not be addressed properly.
\end{abstract}

Key words: Traffic Jam, Performance Employee, Service quality.

\begin{abstract}
ABSTRAK
Kemacetan masih menjadi masalah utama di kota-kota di Indonesia, termasuk di Kota Bogor. Kemacetan di Kota Bogor sudah hampir menyamai ibu kota Jakarta. Ada banyak faktor yang menyebabkan kemacetan di Kota Bogor. Selain jumlah penduduk Kota Bogor yang semakin bertambah, mobilitas penduduk Kota Bogor juga cukup tinggi. Tujuan penelitian ini adalah untuk mengetahui kinerja pegawai Dinas Lalu lintas dan angkutan jalan Kota Bogor dalam menangani kemacetan di Kota Bogor. Metode yang digunakan dalam penelitian ini adalah metode survey dengan pendekatan kuantitatif. Hasil penelitian menunjukkan bahwa dilihat dari dimensi produktivitas, kualitas layanan, responsivitas, responsibilitas, dan akuntabilitas, berada pada kategori sangat baik. Meskipun hasil penilaian responden pegawai menilai bahwa kinerja pegawai sudah sangat baik, namun menurut pandangan pengemudi, penumpang dan pengguna jalan berbeda bahwa kemacetan di Kota Bogor belum dapat diatasi dengan baik.
\end{abstract}

Kata Kunci: Kemacetan, Kinerja Pegawai, Kualitas Pelayanan. 
Dea Siti Hilmiah Halawi, 2016. Kinerja Pegawai Bidang Pengendalian dan Penertiban Pada Dinas Lalu Lintas dan Angkutan Jalan dalam mengatasi Kemacetan di Kota Bogor. 


\section{PENDAHULUAN}

Kemacetan merupakan masalah perkotaan yang tidak terhindarkan, terutama terjadi pada kota-kota di Indonsia yang mulai tumbuh menjadi kota besar, namun belum dibarengi dengan pembangunan infrastruktur dan kebijakan pengelolaan lalu lintas yang ramah lingkungan. Salah satu kota di Indonesia yang sudah terjebak dengan masalah kemacetan adalah kota Bogor.

Kota Bogor sebenarnya belum menjadi kota besar, namun hanya sebagai kota penyangga ibu kota Jakarta. Jumlah penduduk di Kota Bogor dari tahun ke tahun semakin meningkat, yaitu berdasarkan data statistik pada tahun 2013 sebanyak 1,013,019, sedangkan pada tahun 2014 sebanyak 1.030 .720 penduduk (lihat BPS, 2014).

Kemacetan di Kota Bogor sudah hampir menyamai ibu kota Jakarta. Setiap hari selalu ada saja kemacetan di beberapa titik. Khususnya hari jumat, Sabtu dan minggu terjadi puncaknya kemacetan.

Ada banyak faktor yang menyebabkan kemacetan di Kota Bogor. Selain jumlah penduduk Kota Bogor yang semakin bertambah, mobilitas penduduk Kota Bogor juga cukup tinggi. Jumlah penduduk yang keluar dan masuk Kota Bogor intensitasnya cukup tinggi, misalnya dari arah Kota Bogor ke Ciawi, maupun dari Ciawi ke Kota Bogor (Stasiun kereta api).

Tingginya mobilitas penduduki menyebabkan pertumbuhan angkutan yang semakin tinggi. Data dari Dinas Lalu Lintas dan Angkutan Jalan (DLLAJ) Kota Bogor (tahun 2013) menyebutkan bahwa jumlah kendaraan umum di Kota Bogor sebanyak 3.412 .

Belum lagi angkutan umum yang beroperasi dari kabupaten ke Kota yaitu sebanyak 4.426 angkutan, dengan kapasitas jalan di kota Bogor yaitu seluas 11.850 ha. Hal tersebut menunjukkan rasio pertumbuhan sarana (rata-rata 11,7\%) tidak sebanding dengan pertumbuhan prasarana (rata rata $0,1 \%$ ), sehingga terjadi kemacetan. (Sumber: dllaj.go.id). Tingginya pertumbuhan sarana angkutan tidak dibarengi dengan pertumbuhan prasarana. Mobil semakin banyak, namun jalan masih sempit.

Kemacetan di Kota Bogor, bukan hanya disebabkan oleh banyaknya kendaraan pribadi, melainkan banyak kendaraan angkutan kota. Kebijakan Pemerintah Kota untuk mengeluarkan ijin trayek menjadi penyumbang pertama kemacetan di Kota Bogor. Adapun data Trayek Kendaraan Umum di Kota Bogor, sebagai berikut:

Tabel 1

Jumlah Kendaraan Angkutan Umum Kota bogor

\begin{tabular}{ll}
\hline Trayek & Jml Kend \\
\hline Cipinag Gading - Terminal Merdeka & 58 \\
Sukasari - Terminal Bubulak & 562 \\
Terminal Baranangsiang - Terminal & 382 \\
Bubulak & \\
Warung Nangka - ramayana & 180 \\
Ramayana - Cimahpar & 162 \\
Ramayana - Ciheuleut & 157 \\
Terminal Merdeka - Ciparigi & 216 \\
Warung Jambu - ramayana & 146 \\
Sukasari - Ciparigi & 141 \\
Bantar kemang - Terminal Merdeka & 100 \\
Pajajaran Indah - Pasar Bogor & 53 \\
Pasar Anyar - Cimanggu & 180 \\
Bantar Kemang - Ramayana & 154 \\
Sukasari - Pasir Kuda - Terminal & 120 \\
Bubulak & \\
Sindang barang jero - Terminal & 105 \\
Merdeka & \\
Pasar Anyar - Salabenda & 219 \\
Pomad - Tanah Baru - Bina Marga & 55 \\
Ramayana - Mulyaharja & 58 \\
Terminal Bubulak- Kencana & 38 \\
Pasar anyar- Taman Griya Kencana & 22 \\
Terminal Baranangsiang - Ciawi & 170 \\
Pasar Anyar - Pondok Rumput & 54 \\
Ramayana - Taman kencana - Wr. & 80 \\
Jambu & \\
Jumlah Kendaraan & 3.412 \\
\hline Sumber: Proffl DLLAJ thn 2013) & \\
\hline
\end{tabular}

(Sumber: Profil DLLAJ thn. 2013)

Penerbitan ijin trayek dan pengaturan tertib lalu lintas di Kota Bogor menjadi tanggungjawab Dinas Lalu lintas dan angkutan jalan Kota Bogor. Khusus untuk 
menangani kemacetan ada pada Bidang Pengendalian dan Penertiban.

Bidang Pengendalian dan Penertiban Dinas Lalu Lntas dan Angkutan Jalan Kota Bogor memiliki tugas melakukan pengamanan, pengawalan, dan pengaturan lalu lintas, penggembokan roda kendaraan yang parkir sembarangan, menerjunkan personil beserta jajaran lantas ditempatkan di titik-titik lokasi rawan kemacetan dan menekan agar tidak terjadi pelanggaran parkir baik di trotoar maupun badan jalan diseluruh Kota Bogor, melaksanakan pengaturan dan pengendalian arus lalu lintas di titik lokasi kemacetan.

Efektifitas kinerja DLLAJ, khusunya bidang pengendalian dan penertiban dapat dilihat dari terlaksananya tugas dan fungsi DLLAJ dalam pengawasan dan pengendalian angkutan jalan, pemindahan kendaraan bermotor (penderekan) dan pengendalian roda kendaraan.

Dari hasil pengamatan, menunjukkan bahwa kinerja Bidang Pengendalian dan Penertiban pada Dinas LLAJ tersebut sudah baik, namun dipandang belum efektif karena masih ditemukan kemacetan di berbagai titik rawan kemacetan, seperti di Simpang Ciawi, Tas tajur/ MK/ Pakuan, Cipaku/ Simpangan Cipaku, Jalan Pahlawan/ Bondongan BNR, Simpang empang, Mawar, Simpang Manunggal/ Ciwaringin, Jalan Kapten muslihat, Simpang BTM, Surken, jalan Siliwangi, Jalan Sukasari, Pajajaran, Jalan Lohar, dan sebagainya.

Adapun kemacetan terparah pada 2 tahun terakhir ini, yaitu pada tahun 20142015 ada di persimpangan Ciawi dan tingkat kemacetan tahun 2015 lebih parah daripada tahun 2014. (Sumber: LKPJ Walikota Bogor tahun 2014-2015)

Faktor penyebab kemacetan yang lain adalah antar pengemudi yang suka saling mendahului kendaraan yang lain, pengemudi yang tidak tenggang rasa terhadap yang lainnya, mengemudi dengan kecepatan diluar batas, pejalan kaki yang tidak tertib, pedagang kaki lima yang belum rapi, serta banyaknya pengemudi yang menaikkan jumlah penumpang diluar batas karena mengejar target pendapatan, jalan yang sempit, kurangnya tempat untuk pedagang kaki lima dan sebagainya.

Banyaknya kemacetan di jalan raya dan penyebabnya, mengindikasikan bahwa pengawasan dan pengendalian angkutan di jalan raya belum efektif. Artinya fungsi DLLAJ belum sepenuhnya dijalankan secara efektif.

Untuk itu, harus ada upaya untuk mengatasi masalah ini, dengan tujuan mendeskripsikan dan menganalisis kinerja Bidang Pengendalian dan Penertiban pada Dinas Lalu Lintas dan Angkutan Jalan, faktor penghambat serta faktor pendukung kinerja Angkutan umum perkotaan oleh Bidang Pengendalian dan Ketertiban pada Dinas Lalu Lintas dan Angkutan Jalan Kota Bogor.

\section{MATERI DAN METODE}

Fokus kajian penelitia ini adalah pada kinerja pegawai. Kinerja pegawai merupakan cerminan perilaku pegawai di tempat kerja sebagai penerapan keterampilan, kemampuan, dan pengetahuan, yang memberikan kontribusi atau nilai terhadap tujuan organisasi. Untuk mengetahui kinerja pegawai, penulis menggunakan teori menurut Dwiyanto, dengan dimensi-dimensi sebagai berikut:

1. Produktivitas

2. Kualitas Layanan

3. Responsivitas

4. Responsibilitas

5. Akuntabilitas

Selanjutnya penelitian ini dilakukan dengan menggunakan pendekatan kuantitatif dengan metode survey. Menurut Kerlinger (1973) bahwa penelitian survei adalah penelitian yang dilakukan pada populasi besar maupun kecil, tetapi data yang dipelajari adalah data dari sampel yang diambil dari populasi tersebut, sehingga ditemukan kejadian-kejadian relatif, distribusi, dan hubungan-hubungan antar variabel sosiologis maupun psikologis. 
Penelitian survei pada umumnya dilakukan untuk mengambil suatu generalisasi dari pengamatan yang tidak mendalam. Walaupun metode survei ini tidak memerlukan kelompok kontrol seperti halnya pada metode eksperimen, namun generalisasi yang dilakukan bisa lebih akurat bila digunkan sampel yang representatif (David Kline 1980)

Populasi menurut Sugiyono (2013:297) adalah wilayah generalisasi yang terdiri atas obyek atau subyek yang mempunyai kualitas dan karakteristik tertentu yang ditetapkan oleh peneliti untuk dipelajari dan kemudian ditarik kesimpulannya.

Populasi dalam penelitian ini adalah para pegawai Bidang Pengendalian dan Penertiban Dinas Lalu Lintas dan Angkutan Jalan (DLLAJ) Kota Bogor. Adapun jumlah pegawai Bidang pengendalian dan penertiban pada Dinas Lalu Lintas dan Angkutan Jalan adalah sebanyak 52 orang.

Sampel adalah bagian dari jumlah dan karakteristik yang dimiliki oleh populasi tersebut. Sedangkan teknik sampling adalah teknik pengambilan sampel untuk menentukan sampel yang akan digunakan dalam penelitian (Sugiyono 2013:297)

Adapun untuk menentukan sampel para Pegawai Bidang Pengendalian dan Penertiban pada Dinas Lalu Lintas dan Angkutan Jalan (DLLAJ) Kota Bogor digunakan teknik sampling Jenuh. Teknik ini digunakan untuk semua anggota populasi dijadikan sample atau penelitian yang ingin membuat generalisasi dengan kesalahan yang sangat kecil. Istilah lain sample jenuh adalah sensus, dimana semua anggota polupasi dijadikan sample. (Sugiyono, 2013:93).

Selain menentukan sampel untuk Pegawai Bidang Pengendalian dan Penertiban pada Dinas Lalu Lintas dan Angkutan Jalan (DLLAJ) Kota Bogor digunakan juga sampel untuk para pengemudi, penumpang, dan pengguna jalan guna untuk menunjang hasil penelitian penulis, dengan menggunakan teknik accidental sampling.

Dalam melaksanakan penelitian tentunya ada beberapa tahap-tahap yang harus dilakukan dan dilalui untuk mendapatkan data yang lengkap dengan menggali informasi, adalah sebagai berikut:

\section{Studi Kepustakaan}

Teknik ini dilakukan dengan mempelajari berbagai literatur yang berkaitan dengan materi Kinerja Bidang Pengendalian dan Ketertiban pada Dinas Lalu Lintas dan Angkutan jalan dalam mengatasi Kemacetan di Kota Bogor.

2. Studi Lapangan

Yaitu dengan meninjau secara langsung ke tempat lokasi penelitian, penulis melakukan ini untuk mendapatkan data dan informasi yang berhubungan dengan permasalahan yang dibahas dalam penelitian ini dengan cara :

a. Observasi adalah teknik memperoleh data dengan cara meneliti dan mengamati secara langsung pada sumber data yang akan dianalisis mengenai kinerja Bidang Pengendalian dan Ketertiban pada Dinas Lalu Lintas dan Angkutan Jalan dalam mengatasi Kemacetan di Kota Bogor.

b. Wawancara adalah proses tanya jawab secara lisan (Narbuko dan Achmadi, 1997: 70). Wawancara dilakukan dengan pimpinan dan pegawai bidang pengendalian dan penertiban (DALTIB) pada DLLAJ. Selain itu, wawancara juga kepada para pengemudi angkutan umum, penumpang, dan pengguna jalan di Kota Bogor.

c. Angket merupakan teknik pengumpulan data yang dilakukan dengan cara memberi seperangkat pertanyaan atau pernyataan tertulis kepada responden untuk dijawabnya.

Dalam skala rating scale, responden tidak akan menjawab salahsatu dari jawaban kualitatif yang telah disediakan, tetapi menjawab salah satu jawaban kuantitatif yang telah disediakan. Oleh 
karena itu rating scale ini lebih fleksibel, tidak terbatas untuk pengukuran sikap saja tetapi untuk mengukur persepsi responden terhadap fenomena lainnya, seperti skala untuk mengukur status sosial ekonomi, kelembagaan, pengetahuan, kemampuan, proses kegiatan dan lain-lain. (Sugiyono: 2013).

\section{Pengolahan dan Analisis Data}

Dalam penelitian kuantitatif, analisis data merupakan kegiatan setelah data dari seluruh responden atau sumber data lain terkumpul. Kegiatan dalam analisa data adalah mengelompokkan data berdasarkan variabel danjenis responden, mentabulasi data berdasarkan variabel dari seluruh responden, menyajikan data tiap variabel yang diteliti, melakukan perhitungan untuk menjawab rumusan masalah.

Teknik analisa data dalam penelitian kuantitatif menggunakan statistik dalam penelitian kinerja pegawai bidang pengendalian dan penertiban pada dinas lalu lintas dan angkutan jalan dalam mengatasi kemacetan di Kota Bogor, teknik analisa data penelitian yang digunakna adalah deskriptif. Deskriptif digunakan untuk menganalisa data dengan cara mendeskripsikan atau menggambarkan data yang telah terkumpulsebagaimana adanya tanpa bermaksud membuat kesimpulan yang berlaku umum atau generalisasi.

Untuk mempermudah analisis data dan penarikan kesimpulan maka disamping menggunakan perhitungan persentase juga dilakukan dengan menggunakan statistik deskriptif yaitu dengan menggunakan tabel frekuensi dan menggunakan perhitungan rata-rata (mean). Cara ini biasanya dengan menggunakan perhitungan Weight Mean Score (WMS) yaitu dilakukan pembobotan untuk setiap jawaban pilihan. Dengan pemberian skor tersebut, maka akan diperoleh variasi jawaban yang bergerak 15, karena itu interval antara satu kriteria dengan kriteria lainnya yang diperoleh angka sebesar 0,8. Angka ini diperoleh setelah adanya pengurangan dari nilai tertinggi dikurangi nilai terendah dan dibagi banyaknya alternatif jawaban.

Dari ketentuan di atas, maka tingkat kategori jawaban yang diperoleh ditentukan dengan kriteria penafsiran yang mengacu kepada pendapat Bakri Siregar dalam Romli (2006:70)

Menurut Bakri Siregar $(1981 ; 20)$ data yang diperoleh dari lapangan lalu diolah berdasarkan jawaban responden melalui angket yang menggunakan rumus WMS.

\section{HASIL DAN PEMBAHASAN}

Dari hasil penelitian yang penulis lakukan melalui Kinerja pegawai bidang pengendalian dan penertiban pada Dinas Lalu Lintas dan Angkutan Jalan dalam mengatasi kemacetan, berikut penulis akan menguraikan hasil jawaban-jawaban responden terhadap beberapa indikator pertanyaan yang tertuang dalam angket yang disebar ke 52 orang pegawai di lingkungan kantor DLLAJ Kota Bogor.

Analisis knerja pegawai mengacu kepada pendapat Dwiyanto, dengan dimensi-dimensi sebagai berikut:

a. Produktivitas

b. Kualitas Layanan

c. Responsivitas

d. Responsibilitas

e. Akuntabilitas

Produktivitas, yaitu tidak hanya mengukur tingkat efisiensi, tetapi juga mengukur efektivitas pelayanan. Produktivitas pada umumnya dipahami sebagi ratio antara input dengan output.

Pada Dimensi Produktivitas dalam variabel kinerja bidang pengendalian dan penertiban pada dinas lalu lintas dan angkutan jalan diperoleh dengan nilai akhir 4,46 yang menurut penafsiran berada pada kategori Sangat Baik. Hal tersebut didukung berdasarkan hasil wawancara bahwa pegawai dinas LLAJ dalam melaksanakan pekerjaanya sudah sesuai dengan tugas fungsinya.

Kualitas Layanan, yaitu cenderung menjadi penting dalam menjelaskan kinerja 
organisasi pelayanan publik. Banyak pandangan negatif terbentuk mengenai organisasi publik muncul karena ketidakpuasan publik terhadap kualitas.

Pada Dimensi Kualitas layanan dalam variabel kinerja bidang pengendalian dan penertiban pada dinas lalu lintas dan angkutan jalan diperoleh dengan nilai akhir 4,13 yang menurut penafsiran berada pada kategori Baik.

Walalupun indikator tersebut berada pada kriteria baik, namun didasarkan pada hasil wawancara mengenai informasi yang mudah dalam kualitas layanan kepada beberapa pegawai DALTIB DLLAJ mengemukakan bahwa: "Informasi yang didapatkan sangat sulit, karena kita kekurangan sarana HT (Hand Talky). Karena kegiatan koordinasi di lapangan berjauhan maka perlu adanya pesan komunikasi HT bagi setiap anggota supaya lebih mudah dan cepat menyampaikan pesan berita ataupun perintah.

Responsivitas, yaitu kemampuan birokrasi publik untuk mengenali kebutuhan masyarakat, menyusun agenda dan prioritas pelayanan, dan mengembangkan program-program pelayanan publik sesuai dengan kebutuhan dan aspirasi masyarakat. Dimensi Responsivitas dalam variabel kinerja bidang pengendalian dan penertiban pada dinas lalu lintas dan angkutan jalan diperoleh dengan nilai akhir 4,41 yang menurut penafsiran berada pada kategori Sangat Baik.

Responsibilitas, yaitu menjelaskan apakah pelaksanaan kegiatan birokrasi publik itu dilakukan sesuai dengan prinsip-prinsip administrasi yang benar dengan kebijakan birokrasi, baik yang eksplisit maupun implisit, Lenvine dalam Dwiyanto (2006:51).

Dimensi Responsibilitas dalam variabel kinerja bidang pengendalian dan penertiban pada dinas lalu lintas dan angkutan jalan diperoleh dengan nilai akhir 4,63 yang menurut penafsiran berada pada kategori Sangat Baik. Artinya pelaksanaan kegiatan telah sesuai dengan prinsip administrasi.

Akuntabilitas, yaitu menunjuk pada seberapa besar kebijakan dan kegiatan birokrasi publik tunduk pada para pejabat politik yang dipilih oleh rakyat. Asumsinya ialah bahwa para pejabat politik tersebut karena dipilih oleh rakyat, dengan sendirinya akan selalu memprioritaskan kepentingan publik.

Dimensi Akuntabilitas dalam variabel kinerja bidang pengendalian dan penertiban pada dinas lalu lintas dan angkutan jalan diperoleh dengan nilai akhir 4,3 yang menurut penafsiran berada pada kategori Sangat Baik.

Pegawai bidang pengendalian dan penertiban pada Dinas Lalu Lintas dan Angkutan Jalan Kota Bogor dalam melaksanakan pekerjaan dikerjakan sesuai dengan tugas fungsinya, sehingga diperoleh nilai akhir sebesar 4,38 yang menurut kriteria penafsiran berada pada kategori sangat baik. Artinya kinerja bidang pengendalian dan penertiban Dinas LLAJ Kota Bogor sudah baik.

Dari semua dimensi tersebut, rekapitulasi varibael kinerja pada pegawai bidang pengendalian dan penertiban pada Dinas Lalu Lintas dan angkutan Jalan dalam mengatasi kemacetan di Kota Bogor, dapat dilihat dalam tabel sebagai berikut:

Tabel 4

Rekapitulasi Variabel Kinerja pada pegawai bidang DALTIB pada DLLAJ Kota Bogor

$$
(\mathrm{n}=52)
$$

\begin{tabular}{llrl}
\hline Variabel & \multicolumn{1}{c}{ Dimensi } & M & $\begin{array}{c}\text { Kriteria } \\
\text { Penafsiran }\end{array}$ \\
\hline Kinerja & Produktivitas & 4,46 & Sangat Baik \\
& $\begin{array}{l}\text { Kualitas } \\
\text { Layanan }\end{array}$ & 4,13 & Baik \\
& Responsivitas & 4,41 & Sangat Baik \\
& Responsibilitas & 4,63 & Sangat Baik \\
& Akuntabilitas & 4,3 & Sangat Baik \\
\hline & jumlah & $\mathbf{2 1 , 9 3}$ &
\end{tabular}


Rata - rata Skor

\section{4,38 Sangat Baik}

Sumber: Hasil Penelitian 2016

Berdasarkan tabel tersebut menunjukan Rekapitulasi dari variabel Kinerja bidang pengendalian dan penertiban pada Dinas Lalu Lintas dan Angkutan Jalan dalam menangani kemacetan di Kota Bogor diperoleh skor akhir 4,38.

Maka dapat dilakukan penafsiran bahwa Kinerja Bidang Pengendalian dan Penertiban pada Dinas Lalu Lintas dan Angkutan Jalan berada pada kategori sangat baik. Meskipun hasil penilaian responden pegawai menilai bahwa kinerja pegawai sudah sangat baik, namun menurut pandangan pengemudi, penumpang dan pengguna jalan berbeda. Hal ini didasarkan pada hasil wawancara bahwa "Kemacetan di Kota Bogor belum dapat diatasi dengan baik".

Dari semua indikator di atas, bahwa nilai yang paling rendah adalah Kualitas Layanan. Kualitas Layanan ini, menyangkut kepuasan masyarakat, informasi yang mudah, dan layanan yang murah.

Berdasarkan hasil observasi dan penelitian di lapangan, diperoleh keterangan bahwa menurut pengemudi angkutan, masih banyak tukang parkir liarnya, dibanding dengan petugas DLLAJ di lapangan, sehingga tugas-tugas yang seharusnya dilakukan oleh pemerintah, dalam hal ini pihak LLAJ, malah dilakukan oleh tukang parkir.

Menurut Dwiyanto bahwa penilaian kinerja merupakan suatu kegiatan yang sangat penting sebagai ukuran keberhasilan suatu organisasi dalam mencapai misinya. Hasil penelitian yang dilakukan di Dinas LLAJ Kota Bogor, bahwa penilaian pegawai LLAJ menunjukkan bahwa kinerja berada pada kriteria sangat baik. Sekalipun hasilnya sangat baik, namun menurut hasil di lapangan berbeda. Artinya ada faktor lain yang menghambat kinerja LLAJ Kota Bogor.

$\begin{array}{ccc}\text { Adanya } & \text { faktor lain } & \text { nenurut } \\ \text { Pemerintah } & \text { melalui } & \text { Menteri }\end{array}$

Pendayagunaan Aparatur Negara (Menpan) nomor 81 tahun 1995, dalam konteks kinerja, birokrasi pelayanan publik di Indonesia telah memberikan tujuan dalam pemberian pelayanan, dengan keadilan yang merata. Akan tetapi menurut hasil wawancara dengan beberapa penumpang di Kota Bogor, bahwa belum meratanya sanksi terhadap parkir liar, menunjukkan bahwa keadilan yang dilakukan oleh pegawai LLAJ, belum merata. Selain itu faktor yang mempengaruhi kinerja adalah faktor daya tanggap, faktor kemampuan pegawai, faktor teknologi, dan sebagainya.

Hambatan yang dihadapi oleh pihak Dinas Lalu Lintas dan Angkutan Jalan (DLLAJ) adalah penindakan terhadap angkutan yang melanggar aturan yang mengharuskan didampingi oleh minimal 2 orang polisi. Menurut hasil wawancara, bahwa ketika ada pelanggaran, pihak Dinas Lalu Lintas dan Angkutan Jalan (DLLAJ) tidak bisa sewenang-wenang menindak, karena harus didampingi oleh 2 orang polisi. Ini menunjukkan bahwa penindakan tersebut akan sulit dilaksanakan bagi pihak Dinas Lalu Lintas dan Angkutan Jalan (DLLAJ).

Selain dari itu, hambatan yang lain adalah banyaknya parkir liar, banyaknya pedagang kaki lima (PKL), yang menyebabkan kemacetan di Kota bogor.

Upaya yang saat ini dilakukan oleh pemerintah Kota Bogor khususnya pihak Dinas Lalu Lintas dan Angkutan Jalan dalam mengatasi kemacetan adalah membuat sistem satu arah (SSA) yaitu suatu pola lalu lintas yang dilakukan dengan merubah jalan dua arah menjadi jalan satu arahyang berfungsi untuk meningkatkan keselamatan dan kapasitas jalan dan persimpangan sehingga meningkatkan kelancaran lalu lintas yang biasanya diterapkan diwilayah perkotaan seperti yang dilakukan dari daerah Kebun Raya Bogor. Namun berdasarkan wawancara dengan pengemudi bahwa "sistem SSA ini merugikan kami, karena rute jalan semakin jauh serta kemacetan malah semakin parah." 
Selain itu, upaya yang dilakukan lainnya adalah menindak kendaraan yang parkir sembarangan adalah dengan cara memberi sanksi berupa penggembokan roda kendaraan.

\section{KESIMPULAN DAN IMPLIKASI}

Berdasarkan penelitian mengenai kinerja bidang pengendalian dan penertiban pada Dinas Lalu Lintas dan Angkutan Jalan dalam mengatasi kemacetan di Kota Bogor dapat disimpulkan bahwa:

Setelah dilakukan analisis terhadap setiap indikator dari variabel kinerja pegawai, diketahui bahwa skor rata-rata hasil penilaian pegawai bidang pengendalian dan penertiban pada Dinas Lalu Lintas dan Angkutan Jalan untuk seluruh indikator adalah sebesar 4,38 dan menurut kriteria penafsiran berada pada klasifikasi penilaian Sangat baik, dengan demikian penilaian kinerja bidang pengendalian dan penertiban pada Dinas Lalu Lintas dan Angkutan Jalan dalam mengatasi kemacetan di Kota Bogor Sangat baik.

Walaupun berada pada kategori sangat baik, ada hambatan yang dihadapi oleh pihak pemerintah,khususnya bidang pengendalian dan penertiban pada DLLAJ dalam menangani kemacetan ini adalah dalam hal penindakan terhadap kendaraan, bahwa hal tersebut harus dilakukan dengan minimal 2 orang polisi.

Upaya untuk mengatasi kemacetan tersebut adalah diberlakukannya SSA (Sistem Satu Arah). Sistem ini dilakukan dalam upaya untuk mengurangi kemacetan arus lalu lintas di pusat kota, walaupun hal ini dipandang masih belum efektif.

Berdasarkan kesimpulan tersebut, saran penulis adalah koordinasi antar pihak DLLAJ dan Polisi, sehingga tidak ada miskomunikasi dalam menerapkan hukum terhadap pelanggar di jalan. Selain itu pihak pemerintah seharusnya menerapkan kebijakan dengan mengurangi jumlah kendaraan di Kota Bogor, dengan cara membatasi jumlah penggunaan kendaraan dengan larangan melintas di ruas-ruas jalan tertentu bagi kendaraan yang berusia lebih dari lima tahun. Sedikit demi sedikit, jika hal ini dilakukan di semua ruas jalan, maka pemilik kendaraan akan berfikir untuk menjual kendaraannya sehingga tidak menggunakannya lagi.

Selain itu, Pihak Lalu Lintas dan Angkutan Jalan harus sering bersosialisasi atau bermusyawarah kepada masyarakat dalam hal ini sharing kebutuhankebutuhan yang diinginkan oleh masyarakat, serta adanya kotak saran baik untuk pengemudi, penumpang ataupun pejalan kaki.

Kebijakan yang diterapkan dalam mengatasi kemacetan belum baik, karena masih banyak pihak yang dirugikan,terutama Sopir. Agar kebijakan DLLAJ/ Walikota dapat diterima oleh khalayak luas, maka seharusnya pihak pemerintah menyediakan kotak saran di berbagai tempat-tempat umum, seperti di Halte, dan sebagainya. Selain itu juga pihak pemerintah harus sering melakukan sosialisasi jika ada kegiatan-kegiatan yang menyangkut masyarakat banyak, serta menampung semua aspirasi dari masyarakat, lalu di musyawarahkan bersama-sama.

\section{DAFTAR PUSTAKA}

Sumber Buku:

Falatehan, Faroby A. (2005). Kebijakan mengatasi kemacetan lalu lintas di Kota Bogor (suatu pendekatan analisis hirarki). Thesis. Depok. Indonesia. Fakultas Ekonomi Universitas Indonesia.

Kaswan, dkk. (2015). Pengembangan Sumber Daya Manusia dari konsepsi, paradigma, dan fungsi sampai aplikasi. IKAPI. Alfabeta. Bandung

Keban, Yeremias T. (2014). Enam dimensi strategis administrasi publik (konsep, teori dan isu). edisi ketiga. Yogyakarta. Gava Media. 
Mahmudi (2015). Manajemen Kinerja Sektor Publik. Edisi Ketiga. Yogyakarta

Mangkunegara, Anwar. (2012). Evaluasi Kinerja SDM. PT Refika Aditama. Bandung

Mathis, Robert dan John. H. Jackson. (2001). Manajemen Sumber Daya Manusia. Jakarta.Salemba Empat.

Mayyanti, Desti. Evaluasi Kinerja Angkutan Umum Di Kota Bogor (Studi Kasus: Trayek Angkutan Kota Nomor 03,08, dan 09). Jurnal Teknik Sipil Fakultas Teknik Sipil dan Perencanaan, Universitas Gunadarma. Depok

Wibowo. (2007). Manajemen Kinerja. Jakarta. Edisi keempat. Revisi.PT Raja Grafindo Persada.. Rajawali Press

Moeheriono. (2012). Indikator Kinerja Utama (IKU). Jakarta. PT Raja Grafindo Persada.

Hanggraeni, Dewi. (2012). Manajemen Sumber Daya Manusia. Salemba. Jakarta. Fakultas Ekonomu Universitas Indonesia.

Pasolong, Harbani. (2013). Teori administrasi publik. Bandung. Alfabeta.

Schuler, Randall dan Susan E. Jackson. (1996). Manajemen Sumber Daya Manusia. Jakarta. Erlangga.

Sugiyono. (2013). Metode Penelitian Administrasi. Bandung. CV Alfabeta.

(2013). Metode Penelitian Kuantitatif, Kualitatif, dan Kombinasi (Mixed Methods). Bandung. CV Alfabeta.

Sunyoto, danang. (2015). Manajemen dan Pengembangan Sumber Daya Manusia. Yogyakarta. PT Buku Seru.

Torang Syamsir. (2013). Organisasi dan manajemen. Bandung. Alfabeta.

Veithzal, dkk. (2009). Manajemen Sumber Daya Manusia dari Teori ke Praktik. Jakarta. PT Raja Grafindo Persada.

\section{Dokumen-dokumen:}

Laporan bulanan Pengendalian dan Penertiban Dinas Lalu Lintas dan Angkutan Jalan (2015)
Laporan Keterangan Pertanggung Jawaban (LKPJ) Bidang Perencanaan dan Pelaporan Dinas Lalu Lintas dan Angkutan Jalan 2014 dan 2015

Profil dan direktori Dinas Lalu Lintas dan Angkutan Jalan Kota Bogor. 2015

\section{Sumber Internet:}

http://bps. go.id

http://dllaj.go.id

http://kotabogor.go.id/index.php/show_po st/detail/1118/lakukanterobosan-dengan-memanfaatkanteknologi\#.Vwc4Rvl97IU

http://www.republika.co.id/berita/nasion al/jabodetabek nasional/14/06/12/n71aoz-ini-yangdibutuhkan-kota-bogor-untuk-atasikemacetan 